\section{Prolegómenos}

Derecho y Valores
Prolegómenos. Derechos y Valores

ISSN: 0121-182X

derechos.valores@umng.edu.co

Universidad Militar Nueva Granada

Colombia

Caro Rodríguez, Ana María; Blanco Blanco, Jacqueline RESEÑA DE "EL JURISTA (DIEGO ANTONIO NAVARRO)" DE MARIA ISABEL LORCA MARTIN

Prolegómenos. Derechos y Valores, vol. XIV, núm. 28, julio-diciembre, 2011, pp. 289-290

Universidad Militar Nueva Granada

Bogotá, Colombia

Disponible en: http://www.redalyc.org/articulo.oa?id=87622536019

Cómo citar el artículo

Número completo

- Más información del artículo

Página de la revista en redalyc.org

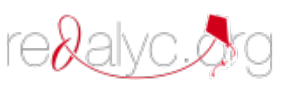

Sistema de Información Científica

Red de Revistas Científicas de América Latina, el Caribe, España y Portugal Proyecto académico sin fines de lucro, desarrollado bajo la iniciativa de acceso abierto 


\title{
RESEÑA: EL JURISTA (DIEGO ANTONIO NAVARRO)*
}

\section{Ana María Caro Rodríguez** Jacqueline Blanco Blanco ***}

\begin{abstract}
Escucha lo que voy a decirte: todo en la naturaleza guarda un misterio. Las aves no ocultan las claves de su vuelo, el agua encierra a buen recaudo el por qué de su extraordinaria fuerza... y si lográsemos que la pintura fuera un reflejo de esa naturaleza, no sería justo incorporar en ella esa misma capacidad para custodiar la información? Cada vez que admires una pintura recuerda que te adentras en la más sublime de las artes. No te quedes nunca en su superficie: penetra en la escena, muévete entre sus elementos, descubre los ángulos inéditos husmea en al trascienda... Y así alcanzaras su verdadero significado. Pero te lo advierto: se necesita valor para ello. No pocas veces lo que encontramos en un mural como este dista de lo que esperábamos hallar. Dicho queda.
\end{abstract}

(Leonardo Da vinci)

"El Jurista" es una obra escrita por la Doctora María Isabel Lorca Martin de Villodres quien retoma la biografía de Don Diego Antonio Navarro Martín de Villodres 1759-1832), religioso perteneciente a la última monarquía de España en Latinoamérica, para llevar a cabo un cuidadoso estudio de tipo histórico y jurídico en el que resalta el papel desempeñado por el prelado en su paso por América del Sur, dentro de un marco de tiempo transcurrido desde la Ilustración europea hasta la reconquista española del territorio americano.

En lo que respecta al modelo francés, la autora destaca el influjo de Rousseau -con su Contrato Social- en cuanto al respeto y cumplimiento de los derechos naturales, con particular atención a la libertad y a la igualdad, en momentos de dominación y de explotación social como ejes de la política colonialista, frente al progresivo e inevitable enfrentamiento dado, a partir de la inconformidad manifestada por los americanos, en razón a su limitado posicionamiento en el campo social, político o económico en el territorio del que eran originales.

En la misma línea la autora suma al papel principal jugado por Rousseau, el legado político y filosófico de Voltaire y Locke, de quienes provino una primaria reacción hacia el sistema Monárquico, para llegar finalmente a una puesta por la libertad política y social fincada en la reinterpretación del sentido de la libertad y la igualdad, tan vejada para entonces. El peso internacional de Francia y sus corrientes teóricas afectó la fecunda y próspera España de los siglos XVI y XVII, que se había consolidado como una Monarquía Católica y que había logrado penetrar el poder político a través del poder religioso.

El aporte que hace la doctora Lorca, maestra de Filosofía del Derecho, está atado a la conmemoración de las independencias latinoamericanas que celebraron algunas naciones en el año 2010, constituyendo la mejor excusa para incorporar un estudio biográfico realizado a un religioso letrado, fiel a la iglesia y al Monarca, que sin duda hace la remembranza perfecta a las circunstancias y al contexto de la obra que se presenta.

* Autora: Dra. MARIA ISABEL LORCA MARTIN, Editorial Dykinson, Madrid. 201, pp.213

** Estudiante de Derecho Universidad Militar Nueva Granada. anamariacaro2003@gmail.com

*** Docente T.C Facultad de Derecho. Universidad Militar Nueva Granada. jacbla201@gmail.com

Bogotá, D.C. Colombia - Volúmen XIV - No. 28 - Julio - Diciembre 2011 - ISSN 0121-182X 
La autora observa la forma como el ilustre prelado, representante de Dios y la Corona, sostiene la responsabilidad de ser fiel a España, lo cual logra a través de su participación social y eucarística, en las que adiciona un peso de influencia sobre el pueblo chileno, con el fin de alejar la más mínima inconformidad entre los naturales americanos, que ya se manifestaban en pro de la independencia, esta acción le ganó al sacerdote Villodres la urgente retirada de Chile y su posterior refugio en Perú. En los escritos del Obispo, como se nombrarán a continuación, se aprecia en forma expresa la antipatía que le despertaba la actitud insurrecta del pueblo chileno:

- El acatamiento al gobierno provisional de la metrópoli, y condena de las ideas independentistas.

- Conocimiento de Derecho público y Derecho Histórico, así como Teología y filosofía.

- El monstruo de la revolución obra de las pasiones y de un desenfrenado egoísmo, no acierta a establecer su trono sin destruir previamente su altar"

Al final del libro, la autora revela la historia del señor Villodres en su regreso a la "Madre
Patria", luego de una serie de detallados insucesos vividos en América, los que nunca compartió por considerar contrarios a su firme convicción a favor de la Monarquía y la religión.

Debe resaltarse como gran legado de la obra, el panorama social y político que rodea tanto al protagonista como al contexto histórico, alrededor del cual se mueve el escrito, constituyendo un importante registro de los acontecimientos que se tejieron en torno al proyecto independentista suramericano, pero visto desde el complejo día a día de un hombre que apegado a sus principios, debió enfrentar con resolución y convicción las contrariedades de un sector, que ya había perdido la fe en el sistema de gobierno peninsular, para pasar a reclamar la reedificación de un Estado propio, autónomo y libre, más cercano a la propuesta francesa que al añejo modelo español.

Bienvenido el trabajo de la doctora Lorca Martín, a la conmemoración de las independencias latinoamericanas, su contribución a la historia política y social de los pueblos del "Nuevo Mundo" quedará inscrita entre los numerosos textos que se proponen, para conocer una nueva versión de lo que muchos creen conocer, pero que textos como estos, indican que aún falta por descubrir. 